$(200)$

$R 290$

$\therefore \quad .70=46$

\author{
UNITED STATES \\ DEPARTMEHT OF THF. IITEERIOR \\ Ceological survey
}

Maps showing locations of holes drilled in 1948 to 1953

by U.S. Geological Survey, Club Mesa area, Hontrose

County, Colorado

By Leonid Bryner

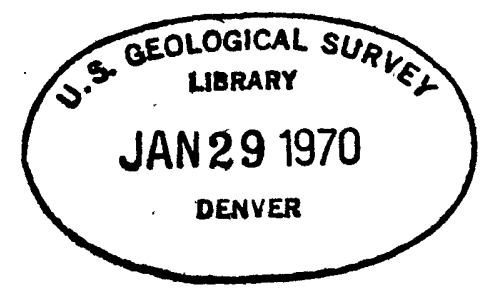

Open-file report

1970

This report is preliminary and has not been edited or reviewed for conformity with U.S. Geological survey standards. 


\section{Maps showing locations of holes drilled in 1948 to 1953 by U.S. Geolorical Survey, Club Mesa area, Hontrose County, Colorado}

Between March 6, 1948, and January 6, 1953, the U.S. Geological Survey drilled 602 diamond-drill holes in the Club Mesa area, Uravan district, Montrose County, Colorado, to explore for uranium-bearing deposits. The deposits are primarily in the Salt Wash Sandstone Member of the Jurassic Morrison Formation.

The maps of the area explored are an index map (fig. 1) and 1 other showing locations of drill holes ( $\mathrm{fig} .2$ ). Logs of 250 holes identified on the accompanying map may be inspected at the U.S. Geological Survey Library, Building 25, Federal Center, Denver, Colo. 80225, and at the U.S. Atomic Enerpy Commission Office, Grand Junction, Colo. 81501. The other 412 holes are on land controlled by the U.S. Atomic Enerpy Commission, and inquiry as to the availability of the lops for them should be directed to that agency. 


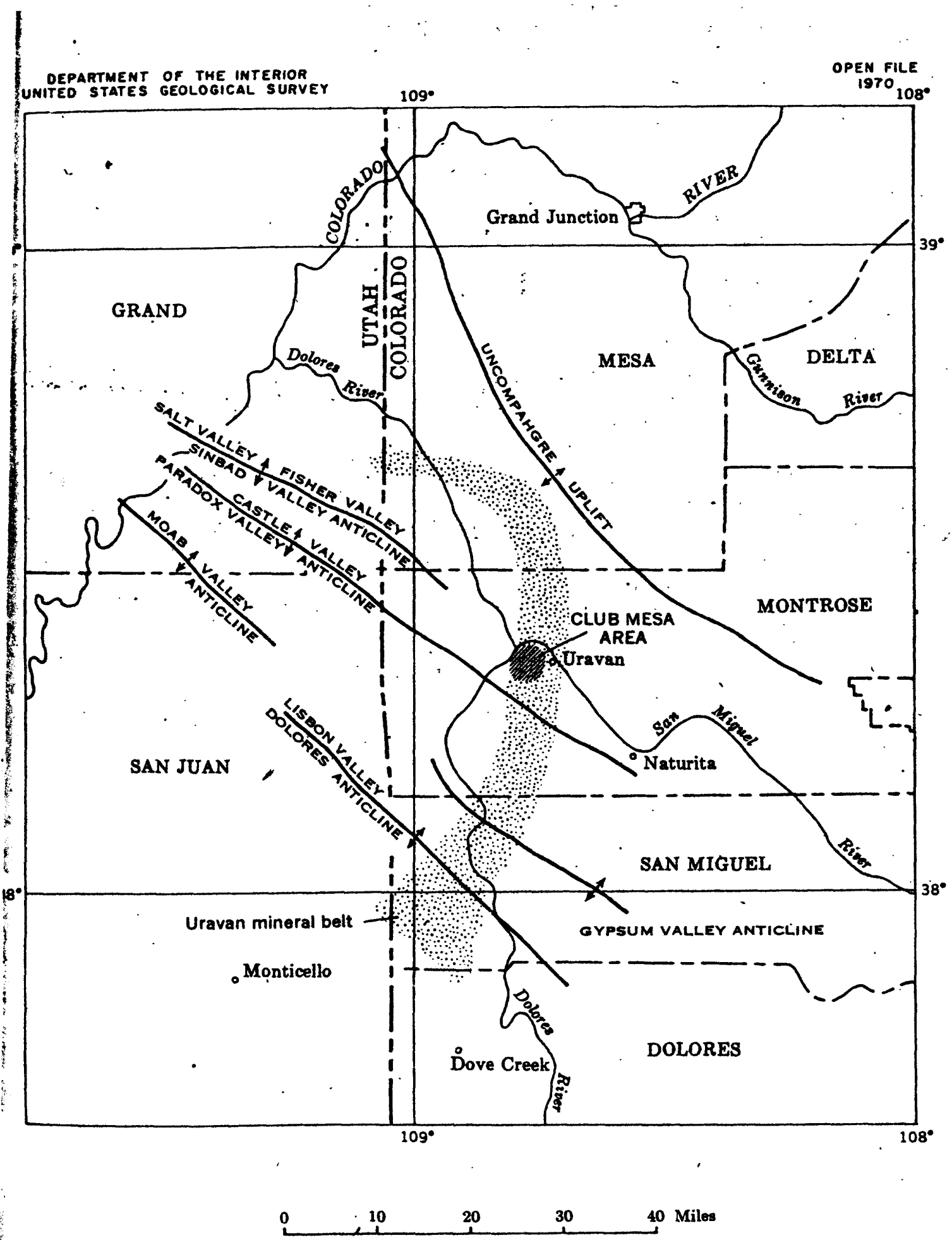

FIGURE 1.--INDEX MAP OF THE EASTERN PART OF THE COLORADO PLATEAU SHOWING THE LOCATION OF CLUB MESA AREA, MONTROSE COUNTY, COLORADO

\begin{tabular}{|c|c|}
\hline & 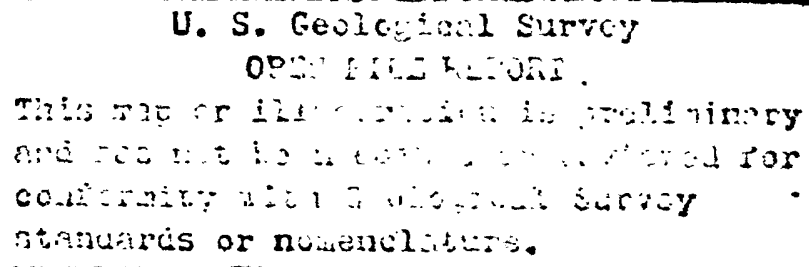 \\
\hline
\end{tabular}

